\title{
Thyrotrophin receptor protein expression in normal and adenomatous human pituitary
}

\author{
M Theodoropoulou ${ }^{1}$, T Arzberger ${ }^{1}$, Y Gruebler $^{1}$, Z Korali $^{1}$, \\ P Mortini $^{3}$, W Joba ${ }^{2}$, A E Heufelder ${ }^{2}$, G K Stalla ${ }^{1}$ and L Schaaf ${ }^{1}$ \\ ${ }^{1}$ Max-Planck Institute of Psychiatry, Department of Endocrinology, Munich, Germany \\ ${ }^{2}$ Zentrum für Innere Medizin, Philipps-Universität, Marburg, Germany \\ ${ }^{3}$ Department of Neurosurgery, IRCSS San Raffaele Institute, Milan, Italy \\ (Requests for offprints should be addressed to L Schaaf, Max-Planck Institute of Psychiatry, Department of Endocrinology, Kraepelinstrasse 10, \\ D-80804 Munich, Germany; Email: schaaf@mpipsykl.mpg.de) \\ (T Arzberger is now at Institute of Pathology, University of Wuerzburg, Germany)
}

\begin{abstract}
Thyrotrophin (TSH) synthesis and secretion is under the positive control of thyrotrophin releasing hormone and under the negative control of the thyroid hormones. However, it is hypothesised that TSH has a direct effect on the regulation of its own synthesis through an intrapituitary loop mediated by pituitary TSH receptors (TSH-R). The aim of this investigation was to study the expression of TSH-R in normal human pituitary at mRNA and protein levels, and to compare the pattern of protein expression between different pituitary adenomas. Using RT-PCR we were able to detect TSH-R mRNA in the normal pituitary, and immunohistochemical studies showed TSH-R protein expression in distinct areas of the anterior pituitary. Double immunostaining with antibodies against each of the intrapituitary hormones and
\end{abstract}

S100 revealed that TSH-R protein is present in thyrotrophs and folliculostellate cells. Examination of 58 pituitary adenomas, including two clinically active and two clinically inactive thyrotroph adenomas, revealed TSH-R immunopositivity in only the two clinically inactive thyrotroph adenomas.

This study shows, for the first time, the presence of TSH-R protein in the normal anterior pituitary and in a subset of thyrotroph adenomas. The expression of TSH-R in the thyrotroph and folliculostellate cell subpopulations provides preliminary evidence of a role for TSH in autocrine and paracrine regulatory pathways within the anterior pituitary gland.

Journal of Endocrinology (2000) 167, 7-13

\section{Introduction}

Thyrotrophin (TSH) is the major regulator of thyroid hormone synthesis and secretion (Magner 1990). Despite the fact that the primary site of action of TSH is the thyroid gland, there is accumulating evidence that there is also extrathyroidal TSH receptor (TSH-R) expression. The extrathyroidal manifestations of Graves' disease, in which TSH-R is considered to represent a major autoantigen (Burman \& Baker 1985), prompted the search and detection of the TSH-R ectodomain in retroocular fibroblasts (Heufelder et al. 1993) and orbital preadipocyte fibroblasts (Bahn et al. 1998), and a TSH-R variant in extraocular muscle (Paschke et al. 1994). TSH-R has also been found to be expressed in thymus, kidney and adrenal cortex (Dutton et al. 1997), cardiac muscle (Drvota et al. 1995), and adipose tissue (Endo et al. 1995).

The cloning of a brain-derived TSH-R, and its localisation in the hypothalamus provided a hint of an additional feedback mechanism in the neuroendocrine control of the thyroid gland, in which TSH is directly involved in the regulation of thyrotrophin releasing hormone (TRH) secretion (Bockmann et al. 1997). On the other hand, it is possible that TSH could exert a tight regulatory control at the level of the pituitary gland.

In this study, we investigated the expression of TSH-R mRNA and protein in the normal human pituitary. In addition we examined the expression of TSH-R in a broad range of different pituitary adenomas.

\section{Materials and Methods}

\section{Materials}

Cell and primary cell culture materials and reagents were obtained from Gibco (Karlsruhe, Germany), Falcon (Heidelberg, Germany), Nunc (Wiesbaden, Germany), and Sigma Chemicals (St Louis, MO, USA). Forskolin and IBMX were obtained from Sigma. 
Human standard pituitary TSH (IRP 80/558) was obtained from the National Institute for Biological Standards and Controls (Potters Bar, Herts., UK), and recombinant human TSH was obtained from GENZYME GmbH (Alzenau, Germany).

\section{Human tissue preparation}

Samples from five human pituitary glands and two thyroid glands were obtained from autopsy cases without any evidence of endocrinological disease, with a post mortem delay of between 8 and $12 \mathrm{~h}$. Additionally, 58 pituitary tumours were obtained after operation: 9 acromegalicassociated adenomas (ACRO), 8 prolactinomas (PROL), 5 Cushing's adenomas (CUSH), 4 thyrotrophinomas (TSH-oma), 19 gonadotrophic adenomas (GONA) and 13 null cell adenomas (NULL). The 4 TSH-omas were further divided into 2 clinically active and 2 clinically inactive TSH-omas. The patients suffering from clinically active TSH-omas had elevated serum TSH levels and clinical signs of hyperthyroidism, and were treated preoperatively with sandostatin. The patients with the hormone inactive $\mathrm{TSH}$-omas were characterised by normal tri-iodothyronine $\left(T_{3}\right)$ and thyroxine $\left(T_{4}\right)$ levels, and the type of adenoma was determined postoperatively by immunohistochemistry. Samples were snap-frozen and stored at $-80{ }^{\circ} \mathrm{C}$.

\section{$R N A$ extraction and RT-PCR}

RNA was extracted from 3 human anterior pituitaries and 2 thyroid glands. One microgram was reverse transcribed as previously described (Pagotto et al. 1995). Two microlitres from the transcription reaction were amplified by PCR $\left(94{ }^{\circ} \mathrm{C}\right.$ for $45 \mathrm{~s}, 58{ }^{\circ} \mathrm{C}$ for $45 \mathrm{~s}, 72{ }^{\circ} \mathrm{C}$ for $1 \mathrm{~min} ; 35$ cycles; PCR reaction (PCR buffer, $\mathrm{MgCl}_{2}$, dNTP mix, and Taq-polymerase (MBI Fermentas, Vilnius, Lithuania) in a total volume of $30 \mu \mathrm{l}$ ) using DNA primers complementary to the extracellular portion of the human TSH-R (sense primer: 5'- GCCATCAGGAGGAGGA CTT-3'; nucleotides 192-210; antisense primer $5^{\prime}$ CAGGTGTTTCTTGCTATC -3'; nucleotides 856873; fragment size $681 \mathrm{bp}$ ). Fifteen microlitres of the reaction products were separated on a $1 \cdot 2 \%$ agarose gel and visualised by staining with ethidium bromide. Human TSH-R cDNA and reverse transcribed RNA from thyroid tissue were amplified as positive controls.

The integrity of the RNA from each sample was confirmed by PCR for human $\beta$-actin (sense primer: $5^{\prime}$-CTAGAAGCATTGCGGTGGACGATG- ${ }^{\prime}$ and antisense primer: 5- ACGGGGTCACCCACACTG TGC-3'; fragment size $660 \mathrm{bp}$ ).

To screen rat and mouse pituitary cell lines for TSH-R mRNA, another set of TSH-R primers was designed complementary to the extracellular portion of the rat TSH-R (sense 5'-GCGTTACTGCTCTTCCTTCC-3'; nucleotides 710-730, antisense 5'-GACTTTCTTTGAC GCAGGTT-3'; nucleotides 922-941; fragment size $231 \mathrm{bp})$.

\section{Immunohistochemistry (IHC)}

Mouse monoclonal antibody (ab) raised against the C-terminal domain of human TSH-R (amino acids 604764) (Loosfelt et al. 1992, Mizukami et al. 1994), and rabbit antiserum raised against the extracellular human TSH-R domain (amino acids 357-372) (Patibandla et al. 1997) were used at final dilutions of $1: 100$ and 1:250 respectively.

Monoclonal mouse ab were used to assess the expression of pituitary. Antibodies were from Immunotech (Karlsruhe, Germany), unless otherwise stated, and were diluted as follows: anti-follicle-stimulating hormone (antiFSH) 1:800, anti-luteinising hormone (anti-LH) 1:800, anti-TSH 1:800, anti-prolactin (anti-PRL) 1:400, antialpha subunit 1:500, anti-adrenocorticotrophin (antiACTH) 1:100 (Dako Diagnostika, Hamburg, Germany) and anti-growth hormone (anti-GH) 1:800 (generous gift of Dr C J Strasburger, Department of Medicine, University of Munich, Germany). Rabbit antiserum against the folliculostellate cell marker, S100, (Biogenesis, Poole, Dorset, UK) was used at 1:20 dilution.

Sections $(8 \mu \mathrm{m})$ were cut on a cryostat, fixed in freshly prepared $4 \%$ paraformaldehyde for $5 \mathrm{~min}$, and stored in $96 \%$ ethanol. IHC was performed as previously described (Lange et al. 1994) with minor modifications. In brief, sections were incubated in $0.3 \%$ hydrogen peroxide in phosphate-buffered saline (PBS) for $15 \mathrm{~min}$ to block endogenous peroxidase activity, followed by incubation in horse serum diluted 1:10 in PBS to eliminate nonspecific binding. The sections were incubated with the primary $a b$ diluted in PBS overnight at $4{ }^{\circ} \mathrm{C}$. After washing in PBS, sections were incubated in biotinylated horse antimouse or goat anti-rabbit immunoglobulin G (Vector, Burlingame, CA, USA; 1:300 dilution) for $30 \mathrm{~min}$ and in avidin-biotin-peroxidase complex (Vectastain Elite Kit, Vector) for $30 \mathrm{~min}$. Immunoreactivity (ir) was visualised using $1 \mathrm{mg} / \mathrm{ml}$ diaminobenzidine (DAB) as chromogen and $0.01 \%$ hydrogen peroxide as substrate. Between all steps of the staining procedure, the sections were washed three times in PBS for $5 \mathrm{~min}$. Peroxidase reaction was stopped, and after $5 \mathrm{~min}$ in distilled water, sections were counterstained in Toluidine blue, dehydrated and mounted with Entellan.

IHC with antibodies against intrapituitary hormones was performed as described above. Sections were incubated in avidin-biotin-alkaline phosphatase complex (Vectastain Elite Kit, Vector). All buffers used were phosphate-free. Immunoreactivity was detected after incubation in Vector Red (Vector) for $15 \mathrm{~min}$, with $10 \mathrm{mM}$ levamisole (Sigma) added to block endogenous alkaline phosphatase activity. 
Double IHC for the TSH-R and S100 colocalisation was carried out by performing first the IHC for the TSH-R, visualising with $\mathrm{DAB}$, and then the IHC for S100, visualising with Vector Red, according to the protocols described above. All the buffers used were phosphate-free.

Controls for TSH-R and pituitary hormone immunostaining were performed by omitting the primary $a b$.

\section{Primary cell culture and cell lines}

Rat anterior pituitary cell culture was performed as previously described (Stalla et al. 1988). Male SpragueDawley rats were decapitated, and fragments of 10 anterior pituitary glands were mechanically and enzymatically dispersed ( $4 \mathrm{~g} / 1$ collagenase, $0 \cdot 01 \mathrm{~g} / 1$ DNAase II, $0 \cdot 1 \mathrm{~g} / 1$ soybean trypsin inhibitor and $1 \mathrm{~g} / \mathrm{l}$ hyaluronidase II). The pituitary cell viability was $95 \%$ as determined by acridine orange/ethidium bromide staining. Cells were diluted with cell culture medium to a density of $2 \times 105$ cells $/ \mathrm{ml}$, distributed in 24-well tissue culture plates, and maintained at $37^{\circ} \mathrm{C}$ for $3-4$ days before being treated and assayed.

The mouse folliculostellate cell line, TtT/GF (Inoue et al. 1992), kindly provided by Prof. Kinji Inoue (Department of Regulation Biology, Saitama University, Urawa, Japan), and the rat somatomammotroph tumour cell line, GH3, were used for functional assays. TtT/GF and $\mathrm{GH} 3$ cells were grown in 24-well tissue culture plates at $37^{\circ} \mathrm{C}$ and $5 \% \mathrm{CO}_{2}$ in Dulbecco's modified Eagle's medium supplemented with $2 \%$ fetal calf serum (FCS) and $10 \%$ FCS respectively, $2 \cdot 2 \mathrm{~g} / 1 \mathrm{NaHCO}_{3}, 10 \mathrm{mM}$ HEPES, $2 \mathrm{nM}$ glutamine, $2.5 \mathrm{mg} / 1$ amphotericin $\mathrm{B}$, $105 \mathrm{U} / 1$ penicillin-streptomycin, $5 \mathrm{mg} / 1$ insulin, $5 \mathrm{mg} / \mathrm{l}$ transferrin, $20 \mathrm{mg} / 1$ sodium selenite and $30 \mathrm{pM} \mathrm{T}_{3}$.

\section{cAMP radioimmunoassay}

Radioimmunological cAMP determination was performed with a commercial RIA kit from NENTM Life Science Products Inc. (Boston, MA, USA). In brief, rat pituitary, $\mathrm{TtT} / \mathrm{GF}$ and GH3 cells were cultivated until confluency, washed and stimulated with standard human TSH or recombinant human TSH at concentrations of 20, 200, 500 and $1000 \mathrm{ng} / \mathrm{ml}$. Forskolin $(5 \mu \mathrm{M})$ was used as a positive control. The phosphodiesterase inhibitor, IBMX $(5 \mathrm{mM})$, was added to all stimulation solutions. The supernatants were collected and assayed after $4 \mathrm{~h}$ of incubation.

\section{Cell proliferation assay}

$\mathrm{GH} 3$ and $\mathrm{TtT} / \mathrm{GF}$ cell proliferation in responce to TSH stimulation was measured using the WST-1 proliferation assay (Roche Molecular Biochemicals, Mannheim, Germany) which is based on the gratification of mitochondrial succinate dehydrogenase activity. The cell cultures were incubated for three days in medium containing $2 \%$ serum and $100 \mu \mathrm{U} / \mathrm{ml}$ or $1 \mathrm{mU} / \mathrm{ml}$ human standard TSH. WST-1 reagent, made up following the manufacturer's instructions, was added to the cell cultures. After a 2-h incubation period, the absorbencies were determined at $440 \mathrm{~nm}$ using an ELISA plate reader.

\section{Statistics}

Each of the experiments was repeated three times. The individual experiments were performed with quadruplicate wells. ANOVA in combination with Scheffe's test was used for statistics. The data are expressed as means \pm S.D.

\section{Results}

\section{$R T-P C R$}

RT-PCR analysis of all three normal pituitary glands resulted in the amplification of the predicted $681 \mathrm{bp}$ band corresponding to the TSH-R (Fig. 1a). Two thyroid glands were used as a positive control. However, it is well known that TSH-R is expressed in mesenchymal cells such as fibroblasts (Heufelder et al. 1993). RT-PCR studies are limiting as they cannot be used to determine the exact cell types involved; therefore IHC was performed in order to further localise the TSH-R protein within individual cell subpopulations in normal and adenomatous human pituitary.

\section{IHC of normal pituitary}

TSH-R ir was detected in the anterior lobe of all 5 normal pituitaries by both monoclonal and polyclonal antiTSH-R antibodies, being present in a small number of cells mainly located in the periphery, and in some fibroblasts. TSH-R ir was observed in the cytoplasm and the cell membrane (Fig. 1b,c).

To further characterise TSH-R positive areas, IHC was performed for each of the pituitary hormones in an adjacent section, and for S100 on the same section. TSH-R expression was found in cells immunopositive for TSH (Fig. 2a,b). However, the number of TSH-R expressing cells was smaller than the number of thyrotrophs. Cell counting revealed that $40 \%$ of TSH immunopositive cells show TSH-R ir. No TSH-R ir was detectable in cell populations immunopositive for ACTH, GH, FSH, LH and PRL. TSH-R ir was also found in cells immunopositive for the follicullostellate cell marker, S100 (Fig. 2c).

\section{IHC of pituitary adenomas}

Of the 58 pituitary adenomas analysed, endocrine cells of ACRO, PROL, CUSH, GONA, NULL and two out 

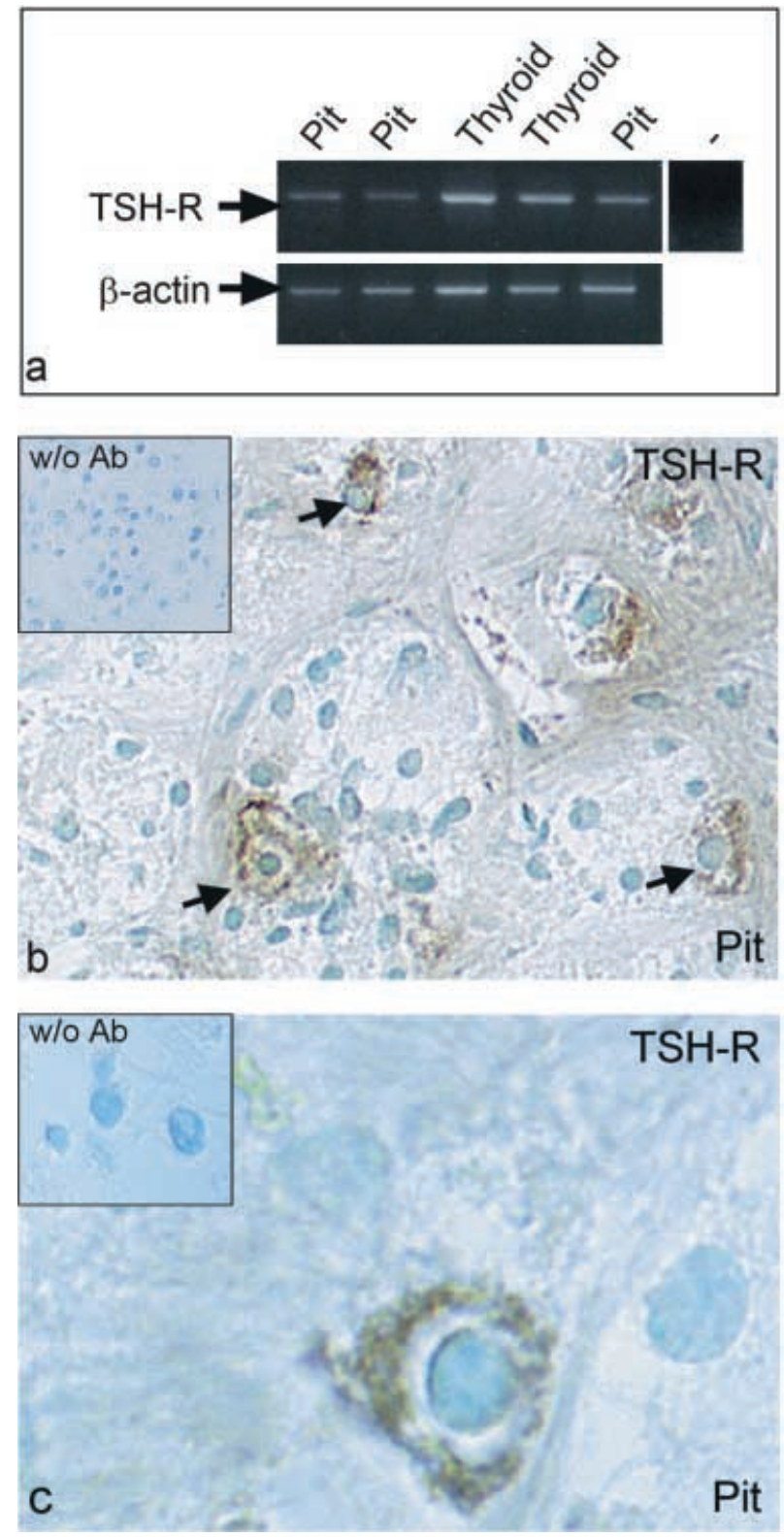

Figure 1 TSH-R expression in normal human anterior pituitary at mRNA (a) and protein (b,c) levels. (a) RT-PCR for TSH-R and $\beta$-actin in 3 normal human pituitaries (Pit) using 2 human thyroid glands as positive controls, and water instead of template as negative $(-)$ control. (b) Some anterior pituitary cells (arrows) show TSH-R ir (objective $20 \times$ ). (c) Higher magnification of a TSH-R immunopositive cell reveals the distribution of ir on the cell membrane and in the cytoplasm (objective $100 \times$ ). In the small icons up-left of each photo is the tissue without the primary antibody (w/o Ab). In this study the monoclonal antibody directed against the C-terminal of the TSH-R was used.

of four of the TSH-omas were negative for TSH-R ir (Fig. 2h). These two TSH-omas were clinically active, since the two patients had high concentrations of circulating thyroid hormones $\left(\mathrm{T}_{3}: 14.5 \mathrm{pmol} / 1\right.$ and $14 \cdot 8 \mathrm{pmol} / 1$, normal values: $4 \cdot 0-7 \cdot 8$; free $\mathrm{T}_{4}: 45 \cdot 3 \mathrm{pmol} / 1$ and $45 \cdot 8 \mathrm{pmol} / 1$, normal values: $13-23)$ but normal/ slightly reduced levels of TSH $(0.21 \mathrm{mU} / 1$ and $0.28 \mathrm{mU} /$ 1; normal values: $0 \cdot 27-4 \cdot 20)$. The other two TSH-omas revealed a significant number of TSH-R immunopositive cells (Fig. 2f). These two adenomas were characterised as clinically nonfunctioning pituitary adenomas (the two patients had TSH $\beta, T_{3}$ and free $T_{4}$ values within the normal range).

To further assess the distribution of hormone producing cells in each tumour, and to detect the areas of normal pituitary tissue, immunohistochemical examination was performed on each tumour for all the pituitary hormones. IHC of the four TSH-omas revealed that the two clinically active tumours expressed lower levels of TSH ir (Fig. 2g) compared with the two clinically nonfunctioning TSH-omas, where TSH ir was very intense (Fig. 2e).

\section{Functional analysis}

PCR studies in pituitary cell lines showed TSH-R mRNA in the rat somatomammotroph tumour cell line, $\mathrm{GH} 3$, and the mouse folliculostellate cell line, TtT/GF (data not shown). Therefore, we used these two cell lines as models to perform cAMP and proliferation assays. Following stimulation with standard or recombinant human TSH, no increase in cAMP levels was detected in the case of GH3 cells. In contrast, TtT/GF cells showed a modest increase in cAMP levels after stimulation with 1000 ng/ml human TSH (Fig. 3). The same experiment was repeated in rat pituitary primary cell culture and gave negative results.

The WST-1 proliferation assay failed to reveal any changes in proliferation after TSH stimulation in rat pituitary primary culture and in TtT/GF and GH3 cells (data not shown).

\section{Discussion}

In this study, we demonstrate the presence of TSH-R at both mRNA and protein levels in the human anterior pituitary. Moreover, we show by immunohistochemical analysis that TSH-producing cells and folliculostellate cells are the sole source of TSH-R ir.

Analysis of TSH-R ir in 58 pituitary adenomas revealed positive staining in only two TSH-omas, both of which were clinically inactive. The number of TSH-R immunopositive cells was lower than the number of TSH immunopositive cells. On the other hand, the number of TSH-R immunopositive thyrotrophs was lower in the TSH-omas than in the normal pituitary, in which almost half of the TSH immunopositive cells were displaying TSH-R ir. It is of interest to note that the other two TSH-omas, which were negative for TSH-R, were 

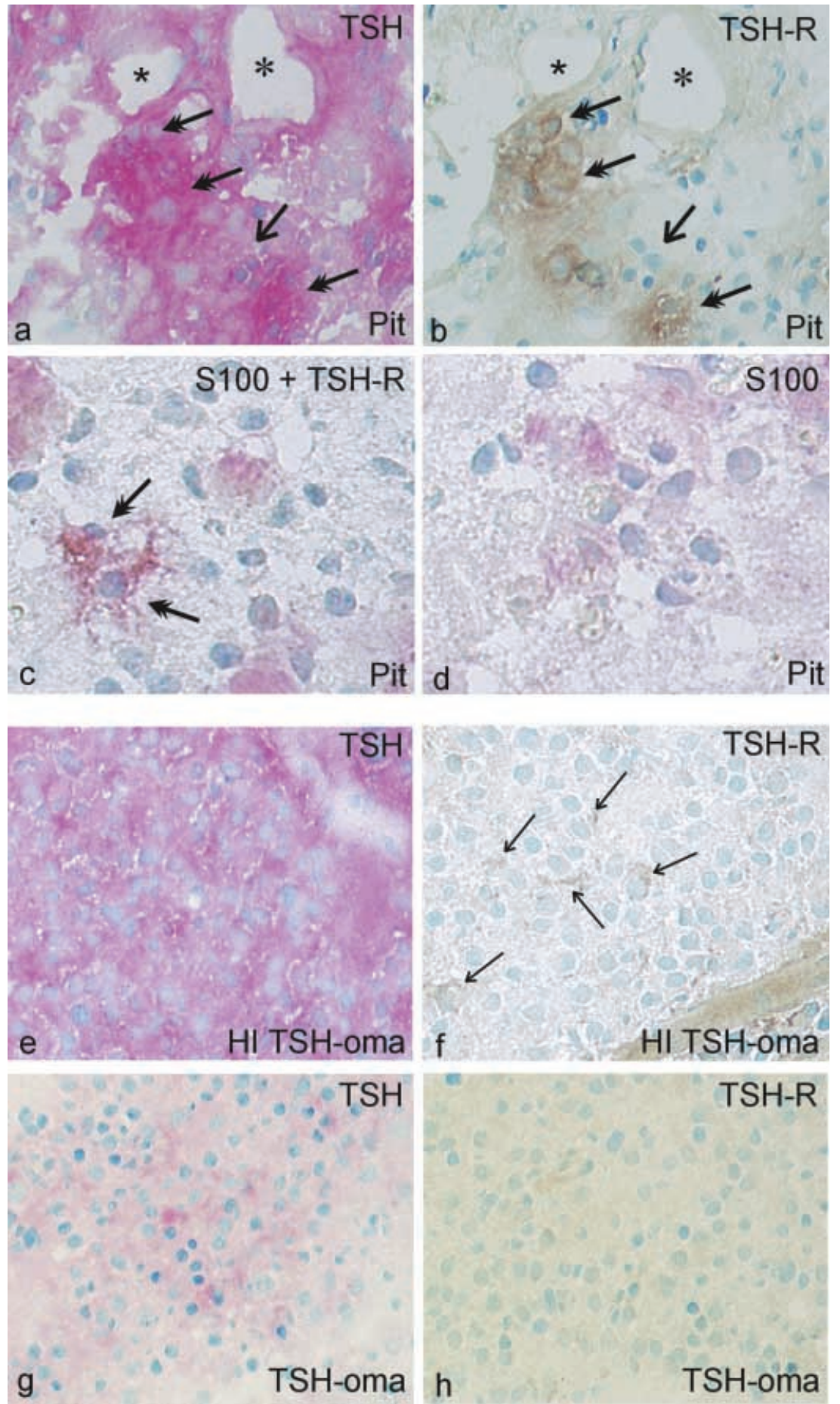

Figure 2 TSH (a) and TSH-R (b) immunostaining in two parallel sections of normal anterior pituitary. Double-headed arrows depict cells which show ir for both TSH and TSH-R, while the single-headed arrows show cells immunopositive for TSH but not for TSH-R. The different types of asterisks represent corresponding regional formations (objective $20 \times$ ). (c) Colocalisation of TSH-R with the folliculostellate cell marker S100 (objective $40 \times$ ). Double-headed arrows depict cells in which S100 and TSH-R colocalise. (d) S100 alone in an adjacent section, as a control. TSH $(\mathrm{e}, \mathrm{g})$ and TSH-R $(\mathrm{f}, \mathrm{h})$ immunostaining in a representative hormonally inactive thyrotroph adenoma (HI TSH-oma), and in a clinically active thyrotroph adenoma (TSH-oma). (e, f) HI TSH-oma has high TSH ir, while the TSH-R is concentrated in few cells indicated by arrows. $(\mathrm{g}, \mathrm{h})$ Clinically active TSH-oma showing weak TSH ir and no TSH-R ir $(\mathrm{objective} 20 \times)$. In this study the monoclonal antibody directed against the C-terminal of the TSH-R was used. 


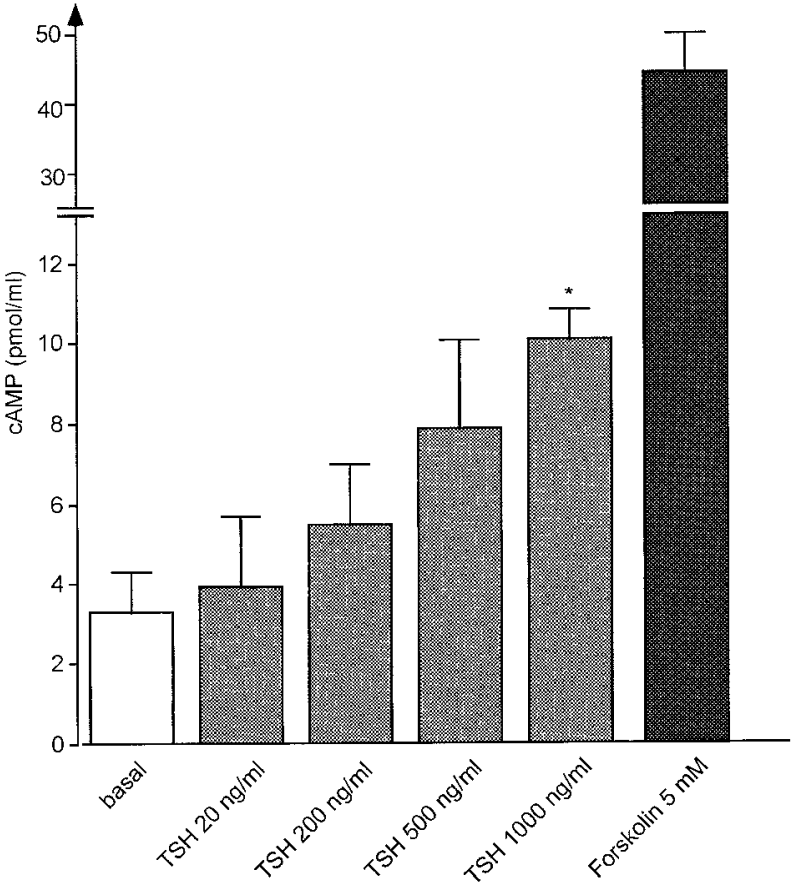

Figure 3 Increase in cAMP after stimulation of the TtT/GF folliculostellate cell line with standard human TSH. Forskolin $(5 \mathrm{mM})$ served as a positive control. ${ }^{*} P<0 \cdot 01 \mathrm{vs}$ basal stimulation.

associated with TSH-dependent hyperthyroidism. Compared with the two clinically inactive TSH-omas, IHC for TSH revealed a smaller number of TSH immunopositive cells, perhaps due to the fact that the patients had received octreotide treatment. It is possible that this treatment is responsible for the absence of TSH-R immunoreactivity in these two TSH-omas. TSH-omas have been reported to display different TSH isoform composition when compared with the normal pituitary, and with other thyreotrophinomas (Magner et al. 1992). Taking into account the fact that TSH synthesis and secretion by TSH-omas escape from the classical feedback control of TRH and thyroid hormones (Beck-Peccoz et al. 1996), it is possible that TSH plays a role in regulating its own synthesis.

The concept of pituitary hormone autoregulation has already been reported for other pituitary hormones. Previous studies have demonstrated the expression of prolactin receptor (Jin et al. 1997) in the normal and adenomatous human pituitary gland. Prolactin receptor mRNA was found to be present in all pituitary cell types and in all types of pituitary adenomas. Prolactinomas showed the highest levels of prolactin receptor expression, and the authors suggested that the regulatory function of prolactin receptor has greater influence on prolactinsecreting cells than any other cell type. Other studies have shown the presence of growth hormone receptor (Mertani et al. 1995), suggesting that growth hormone may have an autocrine action on its own production, and possibly a paracrine action on the synthesis of PRL, FSH and LH. In contrast, TSH-R ir is concentrated only in the thyrotroph cell subpopulation and in a subset of thyreotrophinomas; therefore we conclude that TSH has an autocrine role in the regulation of its own expression and postranslational modification.

In addition, in this study we have identified TSH-R ir in cells immunopositive for the folliculostellate cell marker, S100. While this manuscript was in preparation, Prummel and Brokken (1999) reported the presence of TSH-R ir in folliculostellate cells. Folliculostellate cells comprise $5-10 \%$ of the anterior pituitary cell population, and although their role is still controversial (Allaerts et al. 1990), there is increasing evidence suggesting an important role in the regulation of pituitary function (Schwartz \& Cherny 1992). During the last decade, cell culture studies have demonstrated that folliculostellate cells are involved in the paracrine regulation of hormone secretion through the release of several cytokines and growth factors (Renner et al. 1996). Our demonstration of TSH-R expression in the folliculostellate cell population provides further evidence of a possible role for TSH in intrapituitary regulation, through the release of growth factors.

In view of this possible function of TSH, we attempted to assess whether the pituitary TSH-R is able to stimulate cAMP production, which is known to be the most important TSH-R secondary messenger system in the thyrocyte (Van Sande et al. 1990, Schaaf et al. 1997). We used two cell lines, known to express TSH-R mRNA, and rat pituitary cells in primary culture to examine whether stimulation of the intrapituitary TSH-R is capable of altering cAMP levels. Our results show that TSH has no effect on cAMP when applied to cultured GH3 cells or rat pituitary cells in primary cell culture. In contrast, TtT/GF cells responded with a small increase in cAMP levels following stimulation with TSH. However, the effect was observed after sitmulation with physiologically high concentrations of TSH, and therefore the physiological significance of this finding is questionable. Proliferation assays showed that, unlike the thyroid TSH-R, the intrapituitary TSH-R has no proliferative effect in any of the cell cultures tested. Of note, similar results have been reported for TSH-R in astrocytes, where TSH failed to stimulate cAMP synthesis and phosphatidylinositol hydrolysis, was not mitogenic, and exerted its effect by stimulating arachidonate release and by activating the MAP kinase pathway (Tournier et al. 1995). Whether the intrapituitary TSH-R is coupled to similar alternative pathways must be addressed in subsequent studies.

In conclusion, we demonstrate TSH-R expression at both mRNA and protein levels in the human pituitary gland and in TSH immunopositive pituitary adenomas. These data provide new evidence for a short-loop homeostatic mechanism in which the pituitary thyrotroph may 'sense' the quantity and quality of circulating TSH and adjust TSH secretion and bioactivity in response to the 
endocrine needs of the individual. This effect may involve an alteration of the glycoprotein composition and thus bioactivity of the nascent TSH. Moreover, our demonstration of TSH-R expression by folliculostellate cells favours a paracrine role for TSH within the pituitary. Further studies are needed to explore the significance of the TSH-R and the paracrine and autocrine effects of $\mathrm{TSH}$ in the normal and adenomatous pituitary gland.

\section{Acknowledgements}

The authors are indebted to Mrs J Stalla for excellent technical assistance with the cAMP assays and to Dr P Lohrer for correcting the English in this manuscript. This study was supported by grants from the Deutsche Forschungsgemeinschaft (DFG Scha 701/1-1), and the Forum Schilddrüse e.V. We thank Prof. Bellur Prabhakar, Chicago, USA for his generous supply of the TSH-R antibodies, and the Genzyme GmbH for the generous gift of the recombinant human TSH.

\section{Reference}

Allaerts W, Carmeliet P \& Denef C 1990 New perspectives in the function of pituitary folliculostellate cells. Molecular and Cellular Endocrinology 71 73-81.

Bahn RS, Dutton CM, Natt N, Joba W, Spitzweg C \& Heufelder AE 1998 Thyrotropin receptor expression in Graves' orbital adipose/ connective tissues: potential autoantigen in Graves' ophthalmopathy. Journal of Clinical Endocrinology and Metabolism 83 998-1002.

Beck-Peccoz P, Brucker-Davis F, Persani L, Smallridge RC \& Weintraub BD 1996 Thyrotropin-secreting pituitary tumors. Endocrine Reviews 17 610-638.

Bockmann J, Winter C, Wittkowski W, Kreutz MR \& Bockers TM 1997 Cloning and expression of a brain-derived TSH receptor. Biochemical and Biophysical Research Communications 238 173-178.

Burman KD \& Baker JRJ 1985 Immune mechanisms in Graves' disease. Endocrine Reviews 6 183-232.

Drvota V, Janson A, Norman C, Sylven C, Haggblad J, Bronnegard M \& Marcus C 1995 Evidence for the presence of functional thyrotropin receptor in cardiac muscle. Biochemical and Biophysical Research Communications 211 426-431.

Dutton CM, Joba W, Spitzweg C, Heufelder AE \& Bahn RS 1997 Thyrotropin receptor expression in adrenal, kidney, and thymus. Thyroid 7 879-884.

Endo T, Ohta K, Haraguchi K \& Onaya T 1995 Cloning and functional expression of a thyrotropin receptor cDNA from rat fat cells. Journal of Biological Chemistry 270 10833-10837.

Heufelder AE, Dutton CM, Sarkar G, Donovan KA \& Bahn RS 1993 Detection of TSH receptor RNA in cultured fibroblasts from patients with Graves' ophthalmopathy and pretibial dermopathy. Thyroid 3 297-300.

Inoue $\mathrm{K}$, Matsumoto $\mathrm{H}$, Koyama C, Shibata K, Nakazato Y \& Ito A 1992 Establishment of a folliculostellate-like cell line from a murine thyrotropic pituitary tumor. Endocrinology 131 3110-3116.

Jin L, Qian X, Kulig E, Scheithauer BW, Calle-Rodrigue R, Abboud C, Davis DH, Kovacs K \& Lloyd RV 1997 Prolactin receptor messenger ribonucleic acid in normal and neoplastic human pituitary tissues. Journal of Clinical Endocrinology and Metabolism 82 963-968.
Lange M, Pagotto U, Hopfner U, Ehrenreich H, Oeckler R, Sinowatz F \& Stalla GK 1994 Endothelin expression in normal human anterior pituitaries and pituitary adenomas. Journal of Clinical Endocrinology and Metabolism 79 1864-1870.

Loosfelt H, Pichon C, Jolivet A, Misrahi M, Caillou B, Jamous M, Vannier B \& Milgrom E 1992 Two-subunit structure of the human thyrotropin receptor. PNAS 89 3765-3769.

Magner JA 1990 Thyroid-stimulating hormone: Biosynthesis, cell biology and bioactivity. Endocrine Reviews 11 354-384.

Magner JA, Klibanski A, Fein H, Smallridge R, Blackard W, Young W Jr, Ferris JB, Murphy D, Kane J \& Rubin D 1992 Ricin and lentil lectin-affinity chromatography reveals oligosaccharide heterogeneity of thyrotropin secreted by 12 human pituitary tumors. Metabolism 41 1009-1015.

Mertani HC, Pechoux C, Garcia-Caballero T, Waters MJ \& Morel G 1995 Cellular localization of the growth hormone receptor/binding protein in the human anterior pituitary gland. Journal of Clinical Endocrinology and Metabolism 80 3361-3367.

Mizukami Y, Hashimoto T, Nonomura A, Michigishi T, Nakamura S, Noguchi M \& Matsukawa S 1994 Immunohistochemical demonstration of thyrotropin (TSH)-receptor in normal and diseased human thyroid tissues using monoclonal antibody against recombinant human TSH-receptor protein. Journal of Clinical Endocrinology and Metabolism 79 616-619.

Pagotto U, Arzberger T, Hopfner U, Sauer J, Renner U, Newton CJ, Lange M, Uhl E, Weindl A \& Stalla GK 1995 Expression and localisation of endothelin-1 and endothelin receptors in human meningiomas. Evidence for a role in tumoral growth. Journal of Clinical Investigation 96 2017-2025.

Paschke R, Metcalfe A, Alcalde L, Vassart G, Weetman A \& Ludgate M 1994 Presence of nonfunctional thyrotropin receptor variant transcripts in retroocular and other tissues. Journal of Clinical Endocrinology and Metabolism 79 1234-1238.

Patibandla SA, Dallas JS, Seetharamaiah GS, Tahara K, Kohn LD \& Prabhakar BS 1997 Flow cytometric analyses of antibody binding to Chinese hamster ovary cells expressing human thyrotropin receptor. Journal of Clinical Endocrinology and Metabolism 82 1885-1893.

Prummel MF \& Brokken LJS 1999 Cellular localisation of the thyrotropin receptor in the human anterior pituitary. Journal of Endocrinological Investigation (Suppl no. 6) 33 (Abstract no 65).

Renner U, Pagotto U, Arzt E \& Stalla GK 1996 Autocrine and paracrine roles of polypeptide growth factors, cytokines and vasogenic substances in normal and tumorous pituitary function and growth: a review. European Journal of Endocrinology 135 515-532.

Schaaf L, Leiprecht A, Saji M, Hübner U, Usadel KH \& Kohn LD 1997 Glycosylation variants of human TSH selectively activate signal transduction pathways. Molecular and Cellular Endocrinology 132 185-194.

Schwartz J \& Cherny R 1992 Intercellular communication within the anterior pituitary influencing the secretion of hypophysial hormones. Endocrine Reviews 13 453-475.

Stalla GK, Stalla J, Huber M, Loeffler J-P, Hollt V, vonWerder K \& Mueller OA 1988 Ketoconazole inhibits corticotrophic cell function in vitro. Endocrinology 122 618-623.

Tournier C, Gavaret JM, Jacquemin C, Pierre M \& Saunier B 1995 Stimulation of mitogen-activated protein kinase by thyrotropin in astrocytes. European Journal of Biochemistry 228 16-22.

Van Sande J, Raspe E, Perret J, Lejeune C, Maenhaut C, Vassart G \& Dumont JE 1990 Thyrotropin activates both the cyclic AMP and the PIP2 cascades in $\mathrm{CHO}$ cells expressing the human cDNA of TSH receptor. Molecular and Cellular Endocrinology 74 R1-R6.

Received 7 February 2000

Revised manuscript received 28 April 2000 Accepted 26 May 2000 